\title{
Palaeoecological analysis of phytoplankton regime shifts in response to coastal eutrophication
}

\author{
Dongyan Liu ${ }^{1, *}$, Xuhong Shen ${ }^{1,2}$, Baoping Di ${ }^{1}$, Yajun Shi ${ }^{1}$, John K. Keesing ${ }^{1,3}$, \\ Yujue Wang ${ }^{1}$, Yueqi Wang ${ }^{1,2}$
}

\begin{abstract}
${ }^{1}$ Key Laboratory of Coastal Zone Environmental Processes, Yantai Institute of Coastal Zone Research, Chinese Academy of Sciences; Shandong Provincial Key Laboratory of Coastal Zone Environmental Processes, 264003, Yantai, Shandong, PR China

${ }^{2}$ Graduate University of the Chinese Academy of Sciences, 100049, Beijing, PR China

${ }^{3}$ CSIRO Wealth from Oceans National Research Flagship, Marine and Atmospheric Research, Private Bag 5, Wembley, Western Australia 6913, Australia
\end{abstract}

ABSTRACT: We used a multiple-proxy palaeoecological method to reconstruct a $100 \mathrm{yr}$ time series showing coastal eutrophic processes and phytoplankton responses. Total organic carbon, total nitrogen, diatom frustules, dinoflagellate cysts, brassicasterol and dinosterol were extracted from chronologic sediment cores in Sishili Bay, a polluted area in China. The cores showed that eutrophication occurred during about 1975 to 1985, which corresponds to increased human activity associated with China's economic development since 1978. During eutrophication, the biomass of diatoms and dinoflagellates increased, and dominant species shifted abruptly. The small, heavily silicified diatoms Cyclotella stylorum and Paralia sulcata gradually took the place of the large dominant diatom Coscinodiscus radiatus, while dinoflagellates displayed a progressive increase since 1975. Compared to changes in temperature and rainfall during 1950 to 2010, increased fertilizer use, marine aquaculture and sewage discharge showed a better match to the increasing trend in biomass, species shift and nutrient concentration. Altered nutrient supply ratios caused by increased nitrogen inputs play an important role in the shifts in diatom and dinoflagellate assemblages.

KEY WORDS: Palaeoecology · Eutrophication · Diatom $\cdot$ Dinoflagellate $\cdot$ Biomarkers

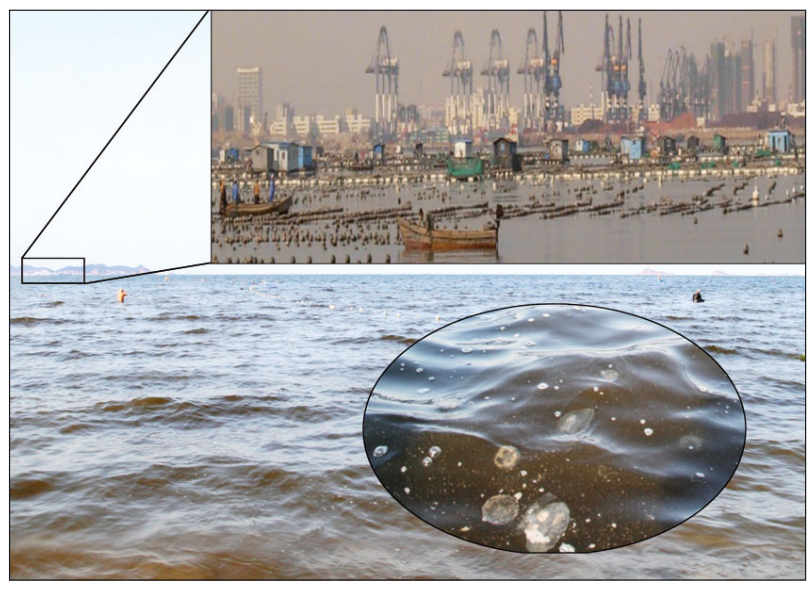

Paleoecological methods make it possible to reconstruct anthropogenic effects such as coastal eutrophication over periods of a century.

Photos: Dongyan Liu \& Zhijun Dong

\section{INTRODUCTION}

Over recent decades, coastal waters have undergone significant deterioration, much of it due to anthropogenic eutrophication (de Jonge et al. 2002) and climate change (Harley et al. 2006). Setting a target for nutrient reduction requires not only information on nutrient sources, distribution and recycling, but also requires knowledge of the trends and baselines of nutrient concentrations in coastal waters 
(e.g. de Jonge \& Essink 1991, Cooper 1995a, Billen \& Garnier 1997, Clarke et al. 2006, Parsons et al. 2006), to determine the effects of anthropogenic activity. Similarly, variations in marine ecosystems responding to eutrophication can be identified objectively against the background of long-term environmental changes. For example, long-term marine observation data (e.g. North Sea, Baltic Sea and Chesapeake Bay) have shown that nutrient enrichment can increase the incidence of phytoplankton blooms and induce a major species shift from diatoms to flagellates at decadal scales (Hickel et al. 1993, Wasmund 2002, Marshall et al. 2009).

In China, a high human population density of $>800$ ind. $\mathrm{km}^{-2}$ living in coastal areas (Ge \& Feng 2009) and rapid economic development since the 1978 economic reforms have produced remarkable anthropogenic impacts along the coastline. Chinese coastal eutrophication is characterized by a dramatic nitrogen overload in the mouths of large rivers (e.g. Yangtze and Pearl Rivers; Huang et al. 2003, Chai et al. 2006) and in coastal waters (e.g. Bohai Sea, Yellow Sea; B. Wang et al. 2003, X. Wang et al. 2009). Consequently, high-biomass algal blooms have increased significantly in Chinese coastal waters since the 1980s and particularly during the late 1990s (Zhou et al. 2001). However, it is difficult to track the eutrophication history and identify trends in phytoplankton shifts in response to eutrophication processes over recent decades, because long-term and continuous observational data in Chinese coastal waters before the 1990s are very limited.

The development of palaeoceanographical technology provides an effective pathway for understanding past changes in marine environments and the responses of associated organisms. A chronology of environmental and ecological information can be established by extracting the geochemical and biological remains stored in sediments and using a method of multi-proxy analysis (e.g. Cooper 1995a,b, Cornwell et al. 1996, Clarke et al. 2006, Dale 2009). Cooper (1995a) used several geochemical indicators (e.g. organic carbon and biogenic silica) and diatoms for reconstructing a $2000 \mathrm{yr}$ history of sedimentation, eutrophication, anoxia and diatom community structure in Chesapeake Bay, USA, and the results indicated that eutrophication began at the time of European settlement of the watershed and increased with increasing land use. Ellegaard et al. (2006) used geochemical and biological proxies in a sediment core to track the eutrophication process in the Danish estuary Mariager Fjord and found that the main changes over the past 100 yr occurred between 1915 and the 1940s, with major species shifts towards those more tolerant to nutrient enrichment.

Among biological proxies (e.g. diatoms, dinoflagellate cysts, foraminifera, pigments, biomarkers) deposited in the sediment, diatom frustules and dinoflagellate cysts display the best representation of anthropogenic activity in coastal lagoons (Andersen et al. 2004), for several reasons: (1) they are the major primary producers in most marine ecosystems and are sensitive to various environmental changes (such as temperature, salinity and nutrients; e.g. Cooper 1995a, Parsons et al. 1999); and (2) their key taxonomical features, viz. cell walls, are preserved in the sediment distinctly enough to obtain both species identification and enumeration, and thus to interpret the responses of phytoplankton to environmental change (e.g. Cooper 1995b, Parsons et al. 2002, Feifel et al. 2012). However, factors which create uncertainty in the application of diatom frustules and dinoflagellate cysts have also been found: (1) small colony-forming diatoms $(<20 \mu \mathrm{m})$, which occupy many coastal waters in large proportions, are not well preserved in the sediment, due to their fragile frustules (e.g. Skeletonema costatum, Chaetoceros sp.); thus, the accuracy of identification may be low and enumeration may be underestimated (Battarbee et al. 2001, Sabetta et al. 2005); (2) only $15 \%$ of dinoflagellates (about 200 species) are known to produce resting cysts during their dormancy phase (Matsuoka \& Fukuyo 2000), and this can result in a significant underestimate of the dinoflagellate biomass in the upper water column; (3) some diatom frustules and cysts can be lost during sampling and isolating processes, depending on sample sizes, chemical concentrations, sieve materials and sizes, and sample treatment (Wood et al. 1996, Lignum et al. 2008). Thus, it is important to establish other parameters related to the abundance of diatoms and dinoflagellates to verify the accuracy of biomass estimates.

Sterols are considered the best biomarkers for diatoms and dinoflagellates, due to their biosynthetic specificity and resistance to degradation in the sediment; in particular, dinosterol $(4 \alpha, 23,24$-trimethyl$5 \alpha$-cholest-22(E)-en-3 $\beta$-ol) is produced almost exclusively by dinoflagellates (Withers 1987, Leblond \& Chapman 2000), and brassicasterol (24-methylcholest-5, 22(E)-dien-3-ol) is a biomarker of diatoms (Barrett et al. 1995, Volkman et al. 1998). Although various chemical and physical conditions (e.g. sedimentation rate, temperature, dissolved oxygen, bacteria, and bioturbation; Canfield 1994, Sun \& Wakeham 1998) can affect the sterol concentration in the sediment, particularly in the surface sediment, these 
compounds can be preserved for up to 3 million yr (Rousseau et al. 1995). Changes in the brassicasterol concentration of marine sediments are related to variations in diatoms and primary productivity (Schubert et al. 1998, Hinrichs et al. 1999, Schulte \& Bard 2003). Leblond et al. (2010) reviewed approximately 100 dinoflagellates that can produce over 50 different sterols and found that about two-thirds of the dinoflagellates contained dinosterol. A positive exponential correlation between dinoflagellate cyst concentration and dinosterols was observed in sediments of the Celtic and Irish Seas (Marret \& Scourse 2003); moreover Mouradian \& Panetta (2007) found that the sum of all dinoflagellate-derived sterols shows a better correlation with total dinocyst counts than using only dinosterol.

For this study, we chose Sishili Bay, one of many coastal bays heavily impacted by human activity, located in the northern Yellow Sea, China (Fig. 1), as our study area. The main goals were to track when eutrophication first occurred and to assess how the diatom and dinoflagellate assemblages varied during the rapid phase of coastal eutrophication since 1978. Geochemical parameters (total organic carbon and total nitrogen) in the sediment cores were analyzed. Biomass and species composition of diatom frustules and dinoflagellate cysts in the sediment cores were used as palaeoecological indicators to track the response of phytoplankton to eutrophication over the last $100 \mathrm{yr}$, and brassicasterol and dinosterol to verify the accuracy of the fossil record. Results were eva- luated in the context of increased nutrient loading, changes in phytoplankton assemblages in the upper water body, regional climate change and historic knowledge of Yantai City's development through time.

\section{MATERIALS AND METHODS}

\section{Study area and sampling}

Sishili Bay has an area of about $130 \mathrm{~km}^{2}$ (Fig. 1). It is characterized by a temperate climatic regime, with a sea surface temperature of 23.3 to $27.4^{\circ} \mathrm{C}$ in summer and 2.5 to $5.0^{\circ} \mathrm{C}$ in winter (Jiang et al. 2011). Only 4 small ephemeral rivers (Guangdang, Majia, Xin An and Xiao Yuniao Rivers) flow into the bay, and salinity varies between the wet and dry season from 29.6 to 33.0 (Jiang et al. 2011). The water depth is generally less than $15 \mathrm{~m}$, and hydrodynamic processes are controlled by tide- and wind-induced currents (Zhang \& Dong 1990).

We collected 4 ca. $1 \mathrm{~m}$ long sediment cores off Zhifu Island at Stn A ( $37^{\circ} 38^{\prime} 20.37^{\prime \prime} \mathrm{N}, 121^{\circ} 21^{\prime} 31.03^{\prime \prime} \mathrm{E}$; water depth $\sim 12 \mathrm{~m}$ ) in December 2008 (Fig. 1), using a gravity corer with a $10.5 \mathrm{~cm}$ internal diameter. Visual inspection of the cores after longitudinal cutting displayed fine black sediment and no evidence of macrofauna. The cores were sectioned into $1 \mathrm{~cm}$ intervals within $24 \mathrm{~h}$ of collection and then stored in a freezer at $-20^{\circ} \mathrm{C}$. Sub-samples were freeze-dried

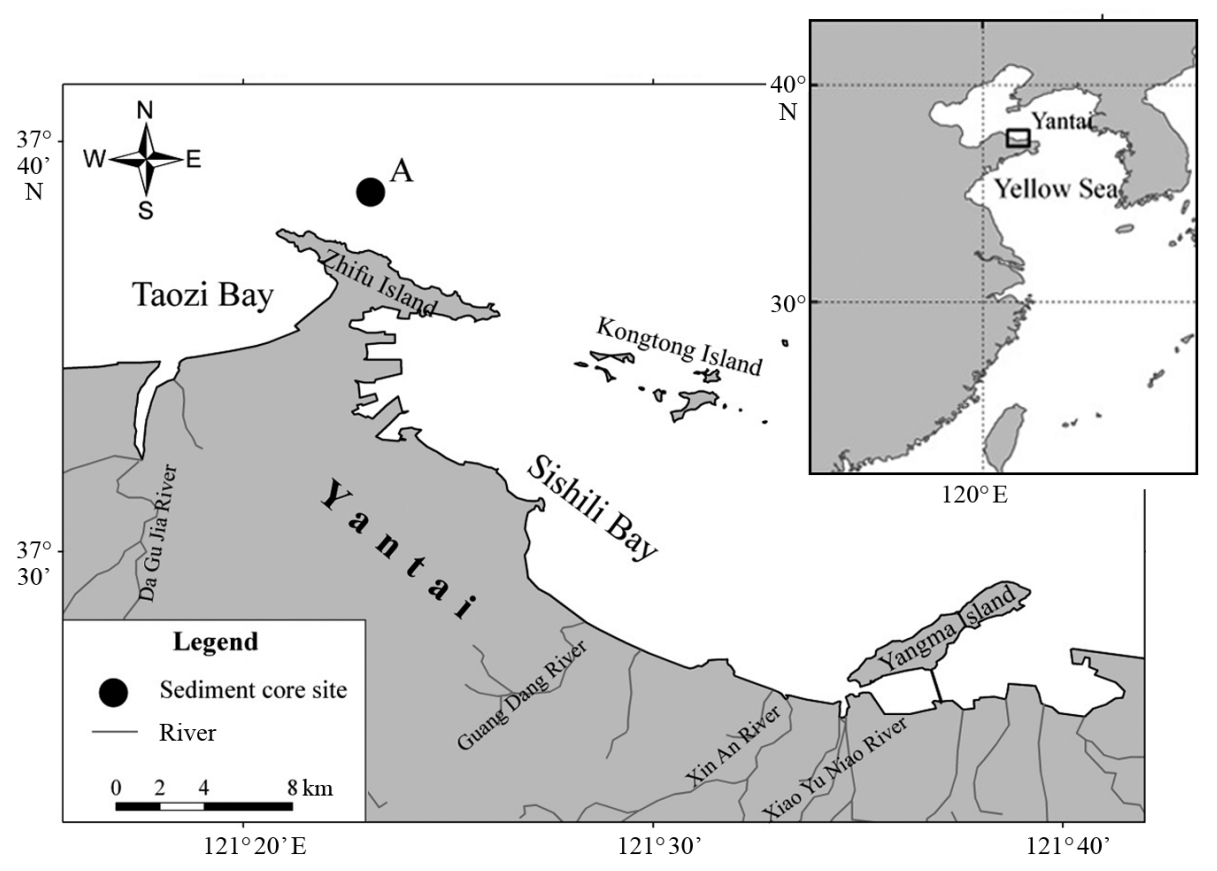

Fig. 1. Study area, showing core sampling site in Sishili Bay, China 
(Christ ALPHA 1-4 LD plus) in the laboratory for biological and geochemical measurements. Core A-1 was used for age measurements; Core A-2 for total organic carbon (TOC), total nitrogen (TN) and grain size analysis; Core A-3 for biomarker extraction; and Core A-4 for diatom frustule and dinoflagellate cyst identification.

\section{Core dating}

${ }^{210} \mathrm{~Pb}$ and ${ }^{137} \mathrm{Cs}$ radiometric-dating techniques (Appleby \& Oldfield 1978, Appleby et al. 1986) were used to measure the chronology of Core A-1 at the Institute of Geography and Limnology, Chinese Academy of Sciences. Radiochemical measurements were performed using well-type Ge detectors (Model Ortec HPGe GWL). ${ }^{210} \mathrm{~Pb}$ and ${ }^{137} \mathrm{Cs}$ activities were estimated after correction with standard samples provided by the Institute of Chinese Atomic Energy Research and the University of Liverpool.

\section{Grain size, TOC and TN analysis}

Grain sizes were measured using a Mastersize 2000 Laser Particle Sizer. The grains were classified into 4 size classes $(<4,4-16,16-64$ and $>64 \mu \mathrm{m})$ representing clay, fine silt, coarse silt and sand. Before grain-size measurements, samples were oxidized using $10 \% \mathrm{H}_{2} \mathrm{O}_{2}$ to remove the organic matter, and dispersed in $0.05 \%\left(\mathrm{NaPO}_{3}\right)_{6}$ solution to isolate discrete particles.

Freeze-dried sediments were homogenized by grinding, and carbonate carbon was removed by adding $1 \mathrm{ml} 0.5 \mathrm{M} \mathrm{HCl}$ to every $100 \mathrm{mg}$ sample, and then rinsed with Milli-Q and freeze-dried for TOC and TN measurements. TOC (\%) and TN (\%) were determined with a Thermo Scientific Flash EA CHNS elemental analyser.

\section{Extraction of biomarkers}

About $5 \mathrm{~g}$ of well-ground, freeze-dried sediment powder was extracted with $\mathrm{CH}_{3} \mathrm{OH} / \mathrm{CH}_{2} \mathrm{Cl}_{2}$ (1:3, v/v) 4 times after the addition of internal standard $\left(\mathrm{n}-\mathrm{C}_{19^{-}}\right.$ $\mathrm{OH})$. The extracts were dried under nitrogen flow and then saponified overnight using $3 \mathrm{ml}$ of $\mathrm{KOH} /$ $\mathrm{CH}_{3} \mathrm{OH}(6 \%, w / v)$. The neutral fraction was extracted with $\mathrm{CH}_{2} \mathrm{Cl}_{2}$ (with $5 \% \mathrm{CH}_{3} \mathrm{OH}$ ) 4 times using a silica column to separate the polar fractions. The polar fractions which included the sterol group were derived by N,O-bis (trimethylsilyl)-trifluoroacetamide at $70^{\circ} \mathrm{C}$ for $2 \mathrm{~h}$ before gas chromatography (GC) analysis.

The lipids in the fractions were quantified using an HP6890 GC fitted with an HP-1 column (50 $\mathrm{m} \times$ $0.32 \mathrm{~mm} \times 0.17 \mu \mathrm{m}, \mathrm{J} \& \mathrm{~W})$ and a flame ionization detector with splitless injection. Both the injector and detector were set at $300^{\circ} \mathrm{C}$. The carrier gas was

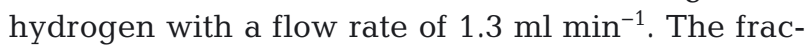
tions were detected with the oven programmed from $80^{\circ} \mathrm{C}$ (held for $1 \mathrm{~min}$ ) to $200^{\circ} \mathrm{C}$ at $25^{\circ} \mathrm{C} \mathrm{min}^{-1}$, followed by $4^{\circ} \mathrm{C} \mathrm{min}^{-1}$ to $250^{\circ} \mathrm{C}$, then $1.8^{\circ} \mathrm{C} \mathrm{min}^{-1}$ to $300^{\circ} \mathrm{C}$ (held for $8 \mathrm{~min}$ ), $5^{\circ} \mathrm{C} \mathrm{min}^{-1}$ to $310^{\circ} \mathrm{C}$ (held for $5 \mathrm{~min})$.

\section{Analysis of diatom frustules and dinoflagellate cysts}

Standard methods were followed for the analysis of diatoms (Battarbee et al. 2001). Sediment samples were dried at $105^{\circ} \mathrm{C}$, and then treated with $10 \% \mathrm{HCl}$ and $30 \% \mathrm{H}_{2} \mathrm{O}_{2}$ to remove carbonate and organic matter, respectively. After rinsing, zinc bromide (specific gravity 2.4) was added to the samples to suspend the siliceous frustules, and then the samples were centrifuged at $760 \times g(10 \mathrm{~min})$. An aliquot of suspended frustules was placed onto a cover slip and then dried. Permanent slides for enumeration were made by mounting the coverslips in Naphrax ${ }^{\mathrm{TM}}$. Frustules were examined under an Olympus CX-31 light microscope. At least 300 valves were counted in each sample, and abundance was calculated as the number of valves per gram of dry sediment (valves $\mathrm{g}^{-1} \mathrm{DW}$ ).

Standard methods were used for the analysis of dinoflagellate cysts (Matsuoka \& Fukuyo 2000). Sediment samples were treated with $10 \% \mathrm{HCl}$ to remove carbonates, while $40 \%$ HF solution was used to remove silicates. After the chemical treatment, samples were sonicated for $30 \mathrm{~s}$ and sieved through 125 and $15 \mu \mathrm{m}$ mesh to remove larger particles (e.g. sand and mud). The residue on the $15 \mu \mathrm{m}$ mesh was collected and suspended in $3 \mathrm{ml}$ of distilled water for cyst identification and enumeration. Dinoflagellate cysts were counted under an inverted microscope (Olympus IX81) at $400 \times$ magnification in a $5 \mathrm{ml}$ tubular plankton chamber (HYDRO-BIOS) after settling for $24 \mathrm{~h}$. For the samples from 0 to $50 \mathrm{~cm}$ sediment depth, at least 300 dinoflagellate cysts were counted in each sample, but for the samples from 50 to $100 \mathrm{~cm}$, only ca. 200 to 300 cysts were counted in each sample due to low abundance. Cyst abundance was calculated as the number of cysts $\mathrm{g}^{-1} \mathrm{DW}$. 


\section{Data analysis}

Linear regression was used to analyse the correlations between diatom and dinoflagellate fossils and their biomarkers. Trends of brassicasterol and dinosterol concentration were analysed using a MannKendall test (Partal \& Kahya 2006) to quantify the turning points of diatom and dinoflagellate assemblages over the last $100 \mathrm{yr}$.

The procedures are:

(1) The lag-1 serial correlation coefficient (R) is computed.

The significance of $\mathrm{R}$ is tested, and if $\mathrm{R}$ is not significant at the $5 \%$ level, then the Mann-Kendall test is applied to original values of the time series. If the calculated $\mathrm{R}$ is significant, a 'pre-whitened' time series obtained is: $X_{0}=\left(X_{2}-\mathrm{R} X_{1}, X_{3}-\mathrm{R} X_{2}, \ldots, X_{\mathrm{n}}-\right.$ $\left.\mathrm{R} X_{\mathrm{n}-1}\right)$, and then iterations are reprocessed until the $\mathrm{R}$ value is not significant at the $5 \%$ level. The new nocorrelation $X$ data series is then used for the MannKendall test.

(2) The Mann-Kendall test is applied.

Under the hypothesis that the time series data $X_{i}(i$ $=1,2 \ldots, \mathrm{n}$ ) are a sample of $n$ independent and identically distributed random variables, the test statistic $S k$ is calculated by their ranks arranged in increasing order:

$$
\begin{gathered}
S k=\sum_{i=1}^{k} r_{i}(k=2,3, \ldots n) \\
r_{i}=\left\{\begin{array}{lc}
+1, & X i>X j \\
0, & \text { else }
\end{array}(j=1,2, \ldots i)\right.
\end{gathered}
$$

and then the sequential values of the statistic $U F(k)$ are calculated as:

$$
U F(k)=\frac{S k-E(S k)}{\sqrt{\operatorname{Var}(S k)}}
$$

$E(S k)$ and $\operatorname{Var}(S k)$ are the mean and variance of the test statistic, respectively. They can be calculated by the following equations:

$$
E(S k)=\frac{k(k-1)}{4}, \quad \operatorname{Var}(S k)=\frac{k(k-1)(2 k+5)}{72}
$$

Similarly, a retrograde time series is computed as the sequential values of the statistic $U B(S k)$. Two curves from the results of $U F(k)$ and $U B(S k)$ are illustrated for trend analysis (see Fig. 7). The values between \pm 1.96 are given at the confidence level $\alpha=$ 0.05 , representing an increasing or decreasing trend, respectively. The values of $|U F|<1.96$ represent a significant trend at the $95 \%$ significance level. The intersection of the 2 curves $U F$ and $U B$ localizes the change and allows identifying the year when the diatom and dinoflagellate shift started (see Fig. 7).

\section{RESULTS}

\section{Geochemical proxies}

Chronology

Unsupported ${ }^{210} \mathrm{~Pb}$ concentrations were variable in the section from 0 to $15 \mathrm{~cm}$ and then declined to a close constant level at 15 to $50 \mathrm{~cm}$ and a slight fluctuation at 50 to $100 \mathrm{~cm}$ (Fig. 2). The variability in ${ }^{210} \mathrm{~Pb}$ activity, particularly over the top $15 \mathrm{~cm}$, supports the application of a Constant Rate of Supply model to estimate the sedimentation rate (Appleby et al. 1986). The average sedimentation rate was calculated as $0.70 \mathrm{~cm} \mathrm{yr}^{-1}$, and the result indicates a time span from ca. 1850 to 2008 (Fig. 2). ${ }^{137} \mathrm{Cs}$ activity began around 1963 (25 to $30 \mathrm{~cm}$ ), and a peak in ${ }^{137} \mathrm{Cs}$ activity between 14.5 and $16.5 \mathrm{~cm}$ is attributed to Chernobyl fallout in 1986, which is in reasonable agreement with the ${ }^{210} \mathrm{~Pb}$ date for these depths (1985 to 1988).

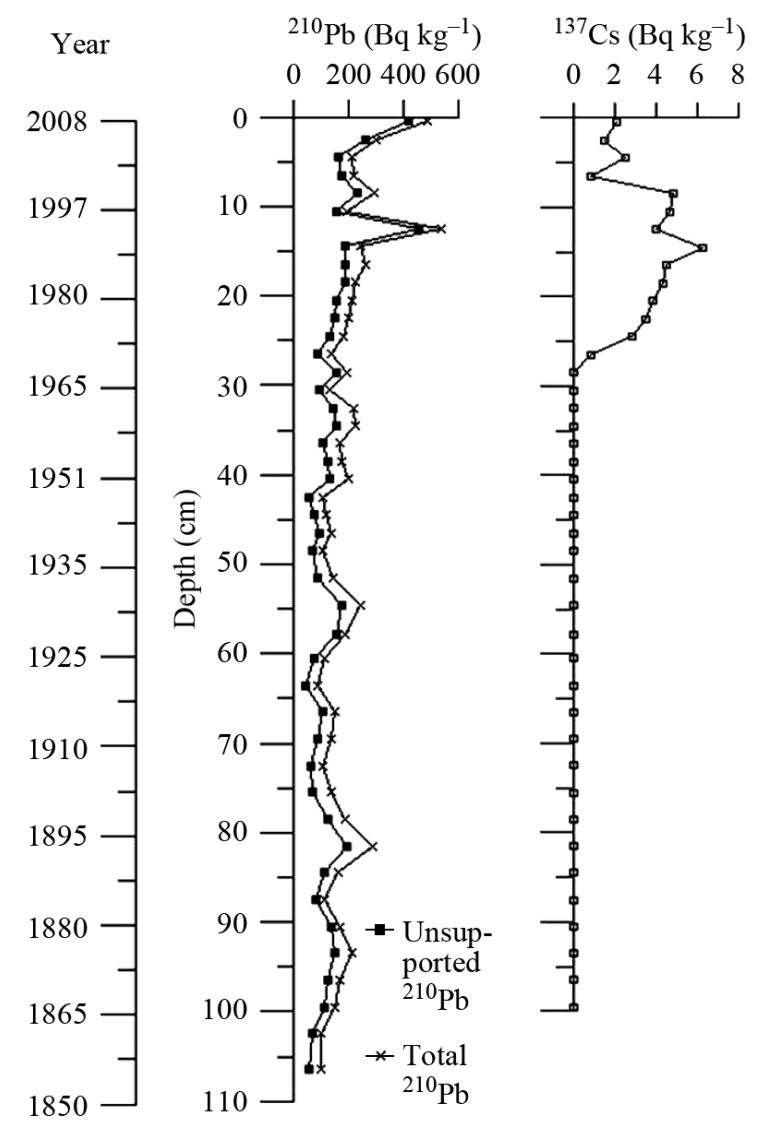

Fig. 2. Depth and age profiles of activity of ${ }^{210} \mathrm{~Pb}$ and ${ }^{137} \mathrm{Cs}$ in Core A-1 


\section{Grain size}

The median sediment grain size was fine silt with a range of 7.8 to $26.1 \mu \mathrm{m}$ (Fig. 3A). The variations in grain size components in the core can be divided into 2 main periods (Fig. 3B-E): (1) grain sizes from 0 to
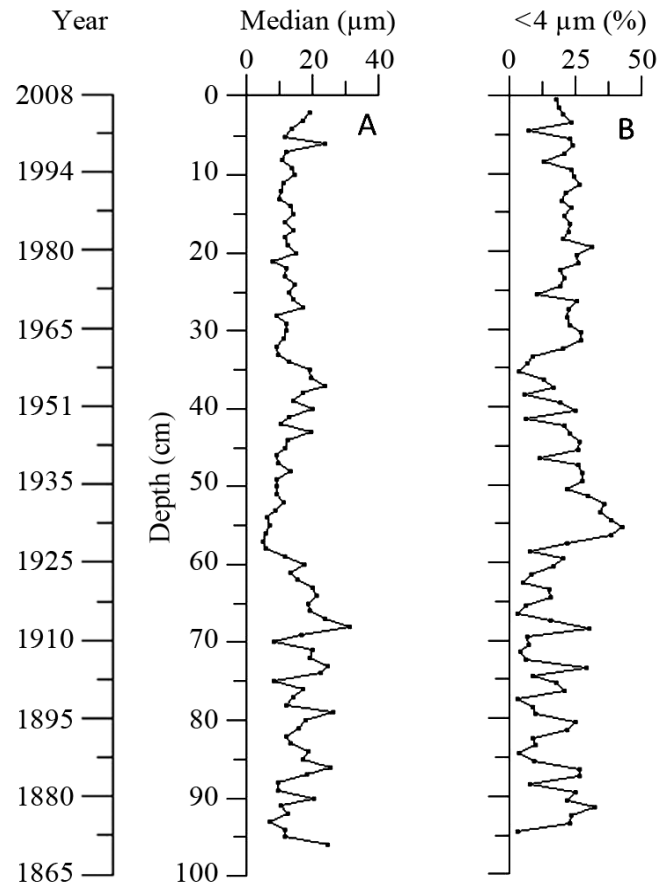

\section{TOC and TN}

TOC and TN showed a gradual increase at 0 to $25 \mathrm{~cm}$ (ca. 1975-2008) and a sudden increase at 35 to $50 \mathrm{~cm}$ (Fig. 3F,G). The increase at 0 to $25 \mathrm{~cm}$ corresponds to a stable sediment grain size, indicating a period of nutrient enrichment in the water column (Fig. 3A,F,G); the increase at 35 to $50 \mathrm{~cm}$ corresponds to a sudden increase in coarse silt (Fig. 3D) and was more likely caused by a disturbance from a flood or other land source.

TOC/TN (C:N) ratios in the core ranged from 8.6 to 9.9 (Fig. 3H). Organic matter dominated by marine phytoplankton generally has $\mathrm{C}: \mathrm{N}$ ratios from 6.7 to 10.1 (Meyers 1994, Stein 1991), so that the organic matter in Sishili Bay is dominated by marine sources, i.e. phytoplankton biomass.
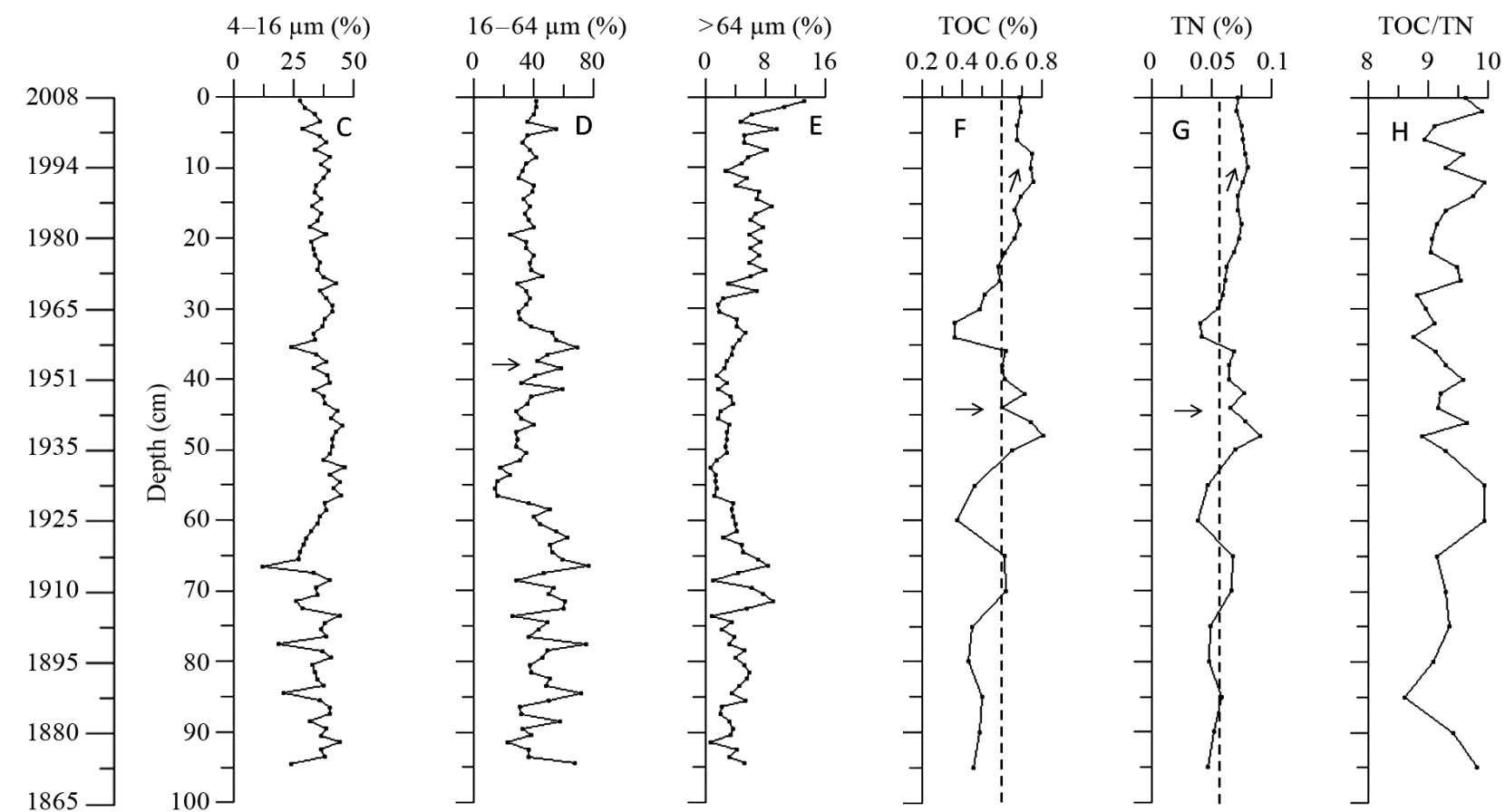

Fig. 3. Depth and age profiles of geochemical parameters in Core A-2 (A-E) sediment grain size; (F) total organic carbon (TOC); $(\mathrm{G})$ total nitrogen $(\mathrm{TN})_{i}(\mathrm{H}) \mathrm{C}: \mathrm{N}$ ratio. Slanted arrows indicate sections of the core with an obvious increasing trend in the variable, and horizontal arrows indicate the part of the core where an obvious change in the data pattern occurs. Dashed line: midrange value (mean of the minimum and maximum values) to illustrate data variation 


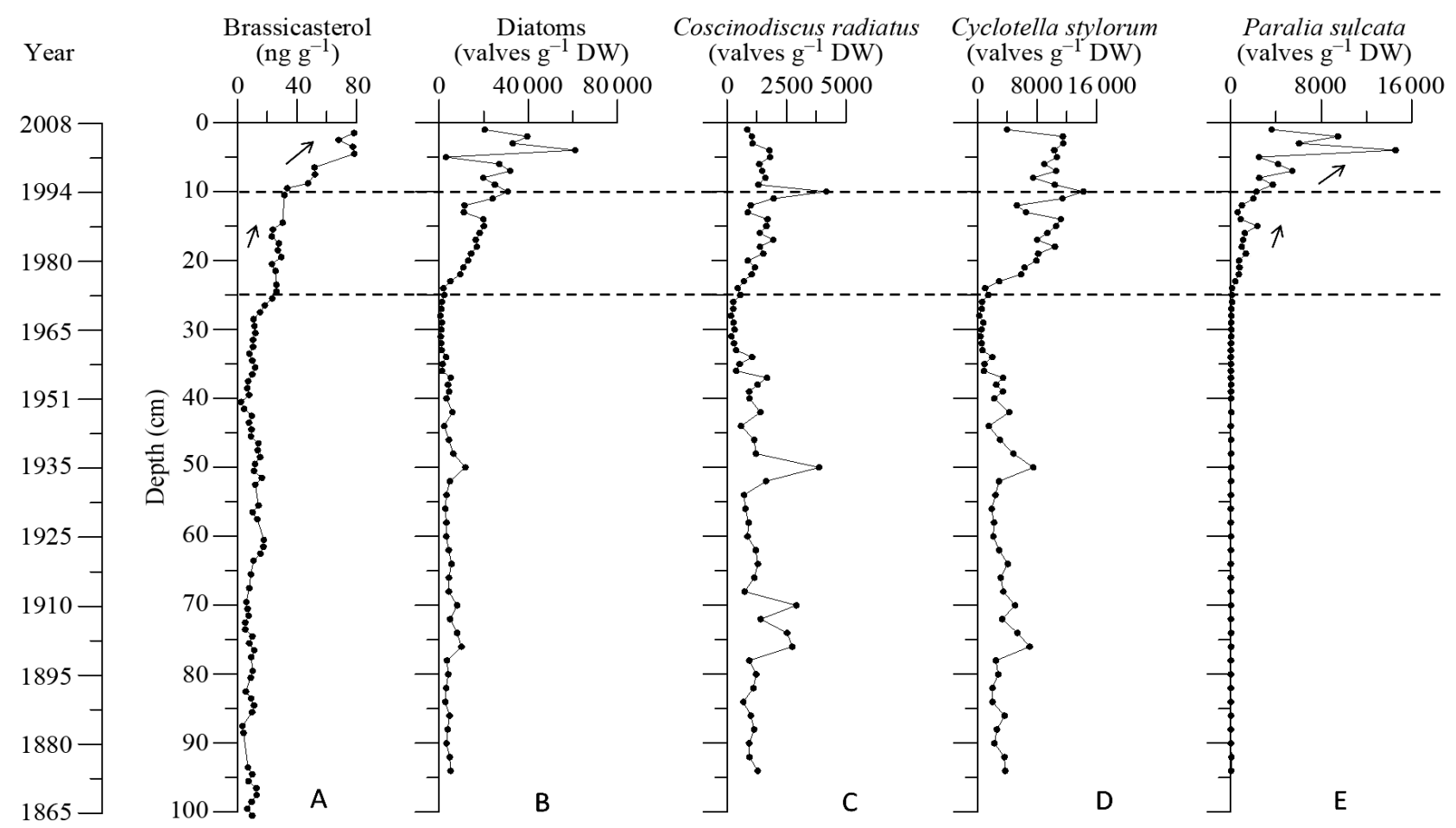

Fig. 4. Depth and age profiles of diatom parameters in the sediment cores: (A) brassicasterol concentrations; (B) diatom frustules; (C-E) dominant species. Slanted arrows indicate sections of the core with an obvious increasing trend in the variable. Dashed lines delimit periods of obvious change in the variable

\section{Diatom and dinoflagellate proxies}

\section{Diatom frustules and brassicasterol}

The variations in brassicasterol concentration in Core A-3 (Fig. 4A) and diatom frustules in Core A-4 (Fig. 4B) displayed similar patterns: (1) a significant increase at 0 to $25 \mathrm{~cm}$ (ca. 1975-2008), which includes a rapid increase at 0 to $10 \mathrm{~cm}$ (ca. 1994-2008) and a relative slower but significant increase at 10 to $25 \mathrm{~cm}$ (ca. 1975-1994); (2) a relatively low biomass at 25 to $100 \mathrm{~cm}$.

Moreover, dominant diatoms displayed a significant shift at $25 \mathrm{~cm}$ (Fig. 4C-E). Cyclotella stylorum and Coscinodiscus radiatus dominated in the whole core, but $C$. stylorum displayed a significant increase in the 0 to $25 \mathrm{~cm}$ section (Fig. 4C,D). Paralia sulcata occurred suddenly at $25 \mathrm{~cm}$ and then increased markedly, becoming dominant. It was particularly abundant at 0 to $10 \mathrm{~cm}$ (Fig. 4E).

\section{Dinoflagellate cysts and dinosterol}

A common pattern of dinosterol concentration (Fig. 5A) and cyst numbers (Fig. 5B) was observed in the core, with higher values at 0 to $25 \mathrm{~cm}$ and lower values at 25 to $100 \mathrm{~cm}$. However, they did not show a synchronous increase and as close a match as the diatoms and brassicasterol. Dinosterol concentration displayed an abrupt increase at 20 to $25 \mathrm{~cm}$ (ca. 1975-1980) and then remained at a stable high level at 0 to $20 \mathrm{~cm}$. In contrast, the variation in cysts was more variable than dinosterol concentration, including an abrupt increase at 10 to $25 \mathrm{~cm}$ (ca. 1975-1994) and a decrease at 0 to $10 \mathrm{~cm}$ (ca. 19942008). These changes are related to variations in dominant species (Fig. 5C-G). For example, the dominant cysts Alexandrium sp., Protoceratium reticulatum and Protoperidinium sp. displayed a significant increase at $25 \mathrm{~cm}$ and then declined at 0 to $10 \mathrm{~cm}$ (Fig. 5C,F,G).

\section{Correlations among biomarkers, diatom frustules and dinoflagellate cysts}

Brassicasterol concentration matched well with that of diatom frustules (Fig. 6A). Correlation between dinoflagellate cysts and dinosterol concentration was also significant (Fig. 6B). This could be related to 2 main factors: (1) some dinoflagellates may not produce dinosterol (Mouradian \& Panetta 2007, Leblond et al. 2010); (2) the numbers of dinofla- 


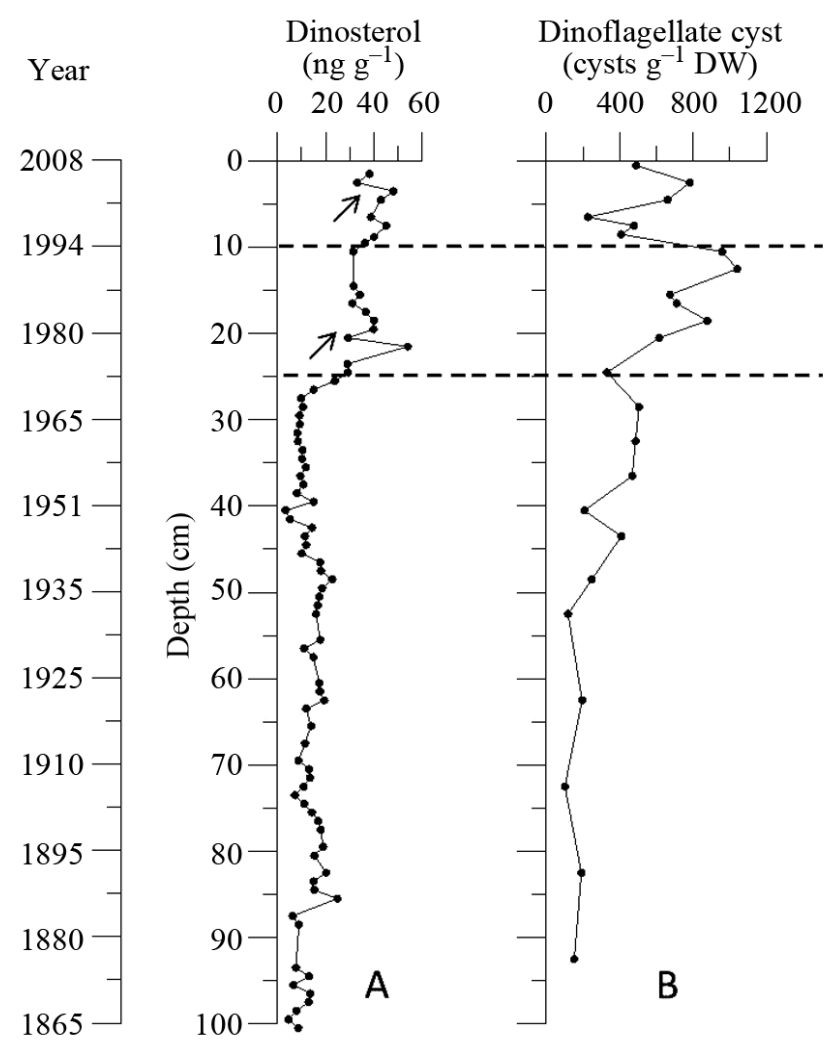

gellates in upper waters that can form cysts are also very important, particularly for dominant species. High-biomass algal blooms were recorded in Sishili Bay after 1998 (0 to $10 \mathrm{~cm}$ in the core; Table 1). Among the blooming dinoflagellates, Akashiwo sanguinea can produce dinosterol (Leblond et al. 2010), although we did not find related resting cysts in the sediment. These factors weaken the correlation between number of cysts and dinosterol concentration. Dinosterol concentration was thus assumed to better represent dinoflagellate biomass in the upper water column than the abundance of cysts. For the above reasons, we used biomarkers for the MannKendall test.

Trend analysis of diatoms and dinoflagellates during 1865 to 2008

Following the Mann-Kendall test, the lag-1 serial correlation coefficient was computed, based on the time series of biomarker concentration, for trend analysis. The intersection between the sequential values

\section{Alexandrium sp. Gonyaulax spinifera Gonyaulax sp. Protoceratium reticulatum Protoperidinium sp. $\begin{array}{lllll}\left(\text { cysts }{ }^{-1} \mathrm{DW}\right) & \left(\text { cysts } \mathrm{g}^{-1} \mathrm{DW}\right) & (\text { cysts g } & & \end{array}$}
$0 \quad 100200$
$0 \quad 40 \quad 80$
$0 \quad 200 \quad 400$
$\begin{array}{lll}0 & 80 & 160\end{array}$
$0 \quad 150300$

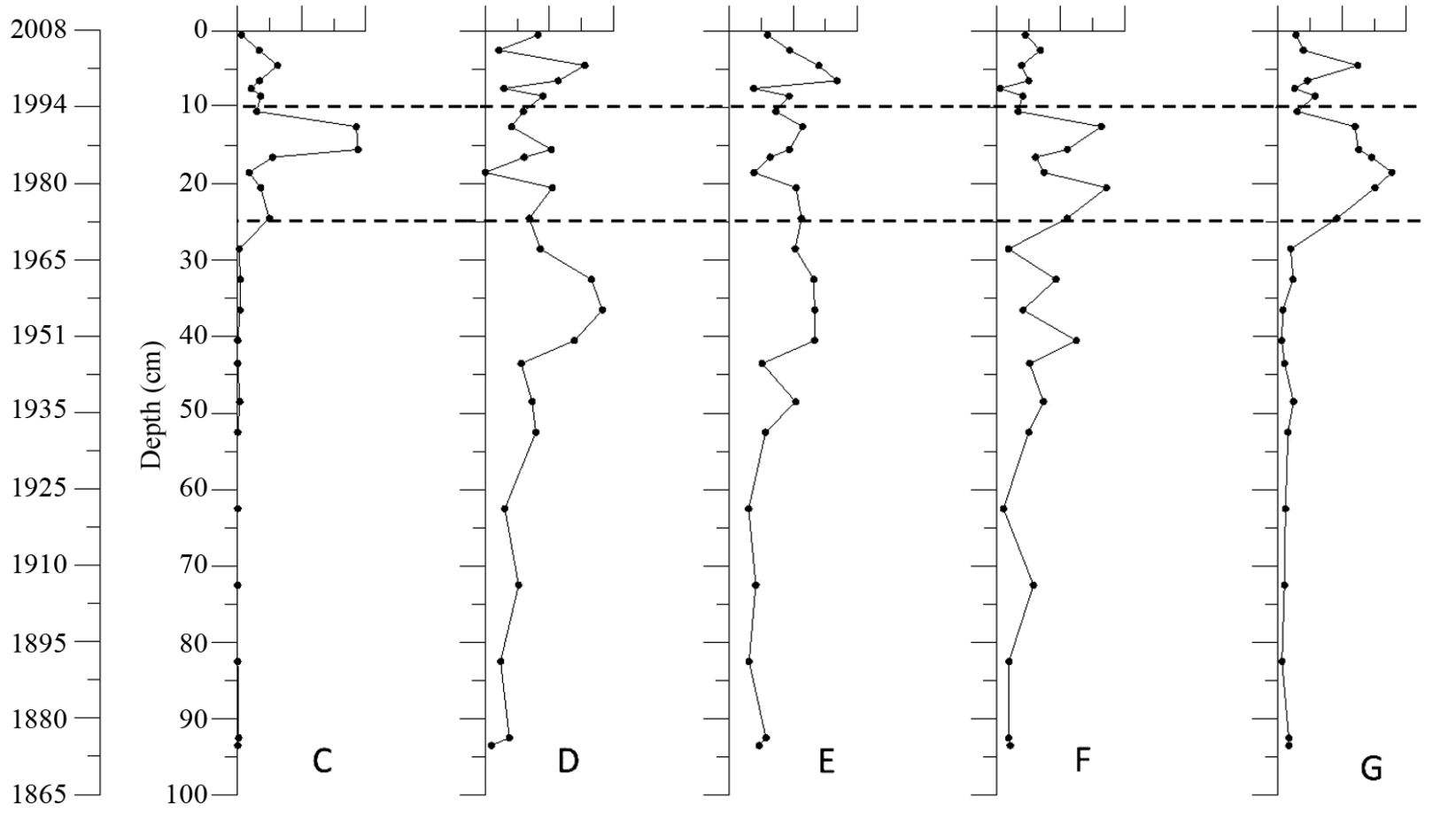

Fig. 5. Depth and age profiles of dinoflagellate parameters in the sediment core: (A) dinosterol concentrations; (B) dinoflagellate cysts; $(\mathrm{C}-\mathrm{G})$ dominant species. Slanted arrows indicate sections of the core with an obvious increasing trend in the variable. Dashed lines delimit periods of obvious change in the variable 

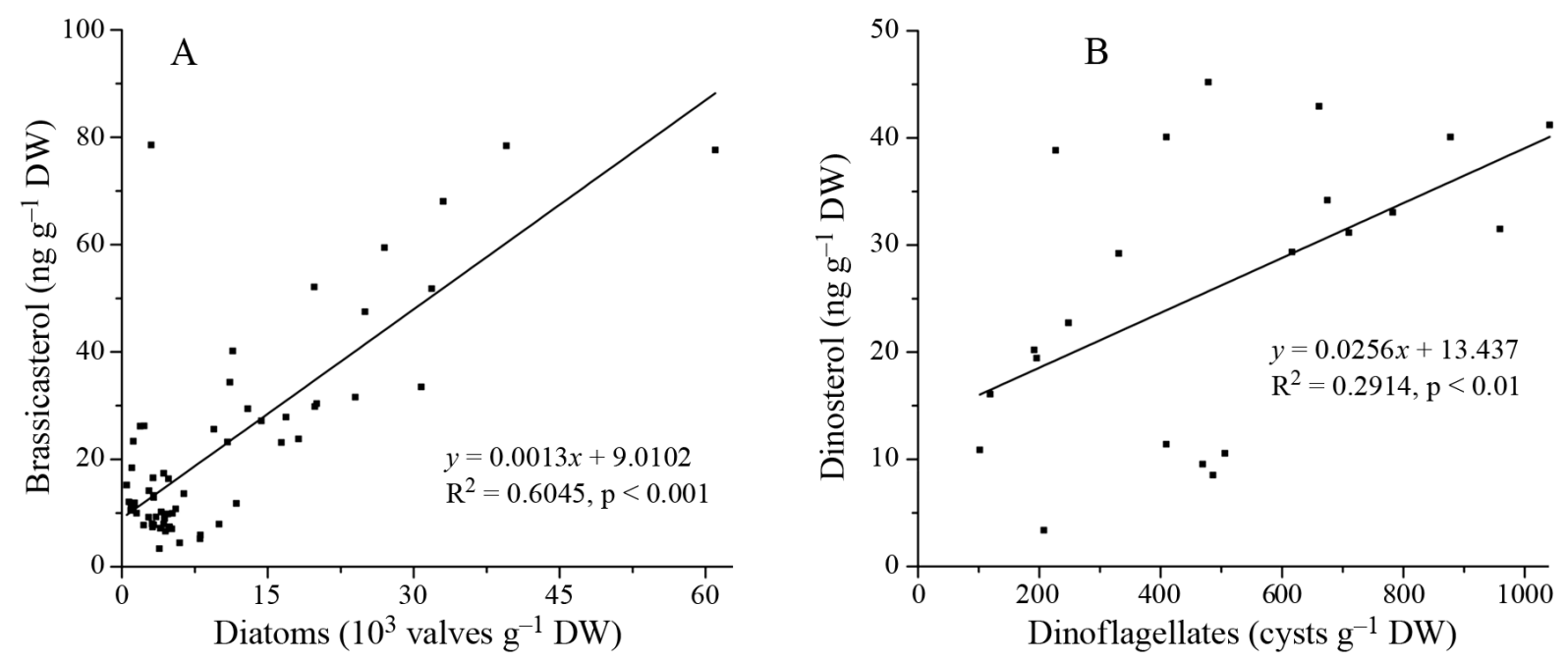

Fig. 6. Correlations (A) between diatoms and brassicasterol concentrations and (B) between dinoflagellate cysts and dinosterol concentrations

of the statistic UF and the retrograde sequential values of the statistic $U B$ curves localized the period when abundance of diatoms and dinoflagellates started to shift (Fig. 7). The result shows that the shift occurred between 1975 and 1985 (at ca. 15 to $25 \mathrm{~cm}$ ) and was accompanied by a significant increase in biomass.

\section{DISCUSSION}

A significant biomass increase and dominant species shift in diatom and dinoflagellate assemblages occurred during 1975 to 1985 , which corresponded to an increase in TOC and TN.

\section{Development of eutrophication in Sishili Bay}

Yantai City, around Sishili Bay, is well known in China for its agricultural products and seafood from marine aquaculture. Thus, we tracked historical fertil-

Table 1. Records of red tides in Sishili Bay during 1998 to 2009

\begin{tabular}{|lclrl|}
\hline Date & $\begin{array}{c}\text { Bloom area } \\
\left(\mathrm{km}^{2}\right)\end{array}$ & \multicolumn{1}{c}{ Species } & $\begin{array}{c}\text { Cell density } \\
\left(\text { ind. } \mathrm{l}^{-1}\right)\end{array}$ & Source \\
\hline Aug 1998 & 100 & Akashiwo sanguinea & $1.56 \times 10^{6}$ & Wu et al. (2001) \\
May 2004 & 26 & Noctiluca scintillans & $2.44 \times 10^{6}$ & Ye et al. (2006) \\
Sep 2004 & 64 & A. sanguinea & $1.03 \times 10^{7}$ & Ye et al. (2006) \\
Aug 2005 & 50 & Prorocentrum micans & $8.1 \times 10^{5}$ & SPOFD (2005) \\
Sep 2005 & 45 & A. sanguinea & $4.09 \times 10^{6}$ & SPOFD (2005) \\
Aug 2007 & 9 & A. sanguinea & $3.29 \times 10^{6}$ & Yu \& Hao (2009) \\
Aug 2008 & 1.65 & Heterosigma akashiwo & $1.3 \times 10^{7}$ & SPOFD (2008) \\
Aug 2009 & 42 & Chattonella marina & $6.7 \times 10^{5}$ & Jiang et al. (2011) \\
\hline
\end{tabular}

izer use, marine aquaculture area, domestic sewage discharge and population increase, to evaluate the links to nutrient enrichment in coastal waters (Fig. 8A-F). Two periods of economic development were identified during the 1970 s to 2000 s, which could have led to significantly increased nutrient levels:

(1) $1970 \mathrm{~s}$ to $1980 \mathrm{~s}$ : agricultural period. A significant increase of fertilizer use started around 1975, reaching a peak of $10.5 \times 10^{5} \mathrm{t}$ in 1980 , and high usage was maintained (Fig. 8A); this was related to agricultural reform in the early stages of Chinese economic reforms during 1975 to 1985 . Increased use of fertilizers can lead to increased nutrient levels in rivers and cause high nutrient flux from rivers to coastal waters.

(2) 1990s to 2000s: aquaculture, and sewage discharge. Limited marine aquaculture activity began in the 1970s and was expanded along the coastline in the 1990s (Fig. 8B), when economic conditions had improved significantly. Suspended scallop aquaculture in the bay carries a standing stock of $30000 \mathrm{t}$ (Zhou et al. 2006). Meanwhile, increased population (Fig. 8C) and industrial activity during the development of urbanization accelerated the need for sewage treatment. In 1997, the Taozi Bay sewage treatment plant near Sishili Bay began operating and discharged about $2.5 \times 10^{5} \mathrm{t} \mathrm{d}^{-1}$ of waste water into coastal waters (Fig. 8D) (Wang \& Li 1997). These activities have significantly increased nitrogen loading in Sishili Bay. A comparison of seawater quality in Sishili Bay between 1997-1998 and 2009-2010 
showed rapid increases in nitrogen concentrations in the bay (Table 2). Moreover, high-biomass algal blooms increased after 1998 (Table 1).

Although many studies have shown that nutrient enrichment is the dominant factor for phytoplankton change in coastal waters, climate signals driving phytoplankton change cannot be ignored (Morán et al. 2010). Increase in temperature and river flow associated with climate change combined with nutrient enrichment can accelerate changes in phytoplankton assemblages (e.g. North Sea; Smetacek \& Cloern 2008). The annual average air temperature in Yantai fluctuated within $2^{\circ} \mathrm{C}$ during the 1950s to $2000 \mathrm{~s}$, and a significant increase (up to $1^{\circ} \mathrm{C}$ ) has occurred since the 1990s (Fig. 8E; Yantai Statistics Bureau 2009). A slight variation in temperature can have a dramatic effect on phytoplankton organisms because of their low temperature compensation ability (Werne et al. 2000). Comparing the timelines, the temperature increase in Yantai lagged behind the first shift in diatom and dinoflagellate abundance
(1975) by about 15 yr. However, increased temperature since the 1990s may have contributed to the significant increase in biomass.

Annual rainfall in Yantai generally fluctuates from 400 to $800 \mathrm{~mm}$. Data from 1950 to 2009 showed a clear, albeit small, decrease in rainfall during 1980 to 1990 (Fig. 8F). This did not coincide with the shift in phytoplankton abundance and increased TOC and TN. Thus, eutrophication masked any effects of climate change in Sishili Bay. However, increased temperature since the 1990s could have enhanced the changes in phytoplankton assemblages.

\section{Implications of the diatom and dinoflagellate species shift}

Excessive nitrogen or phosphate inputs shift the nutrient ratio (N:P:Si) and cause silicate limitation for diatom growth (Egge \& Aksnes 1992). Based on the observed data in Sishili Bay, dissolved inorganic nitro-

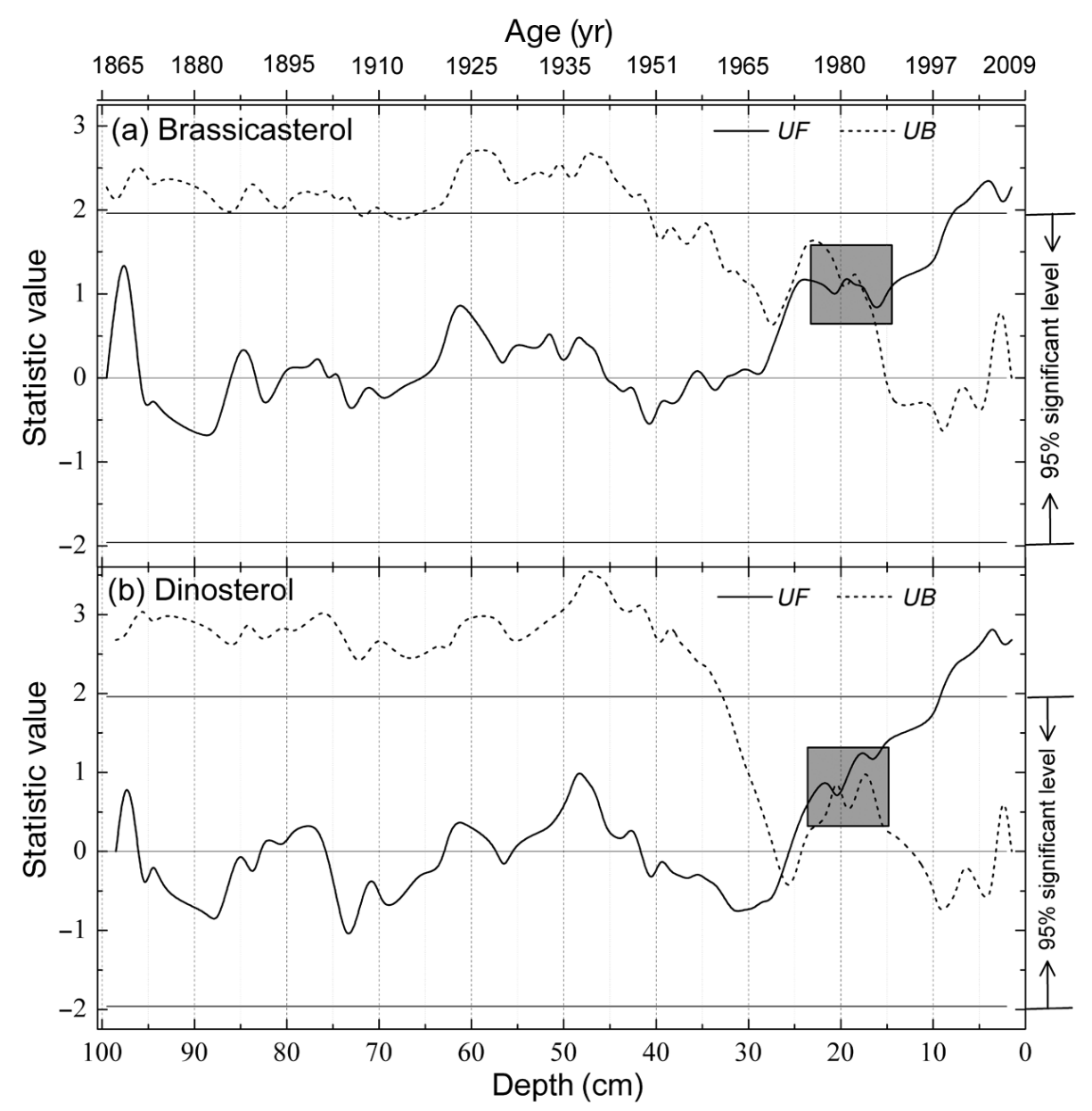

Fig. 7. Trend analysis of (A) brassicasterol and (B) dinosterol concentrations in the sediment core based on a Mann-Kendall test $(\tau)$. The sequential values of the statistic $U F$ and the retrograde sequential values of the statistic $U B$ are shown. Grey boxes: period of regime shift (1975 to 1985) 


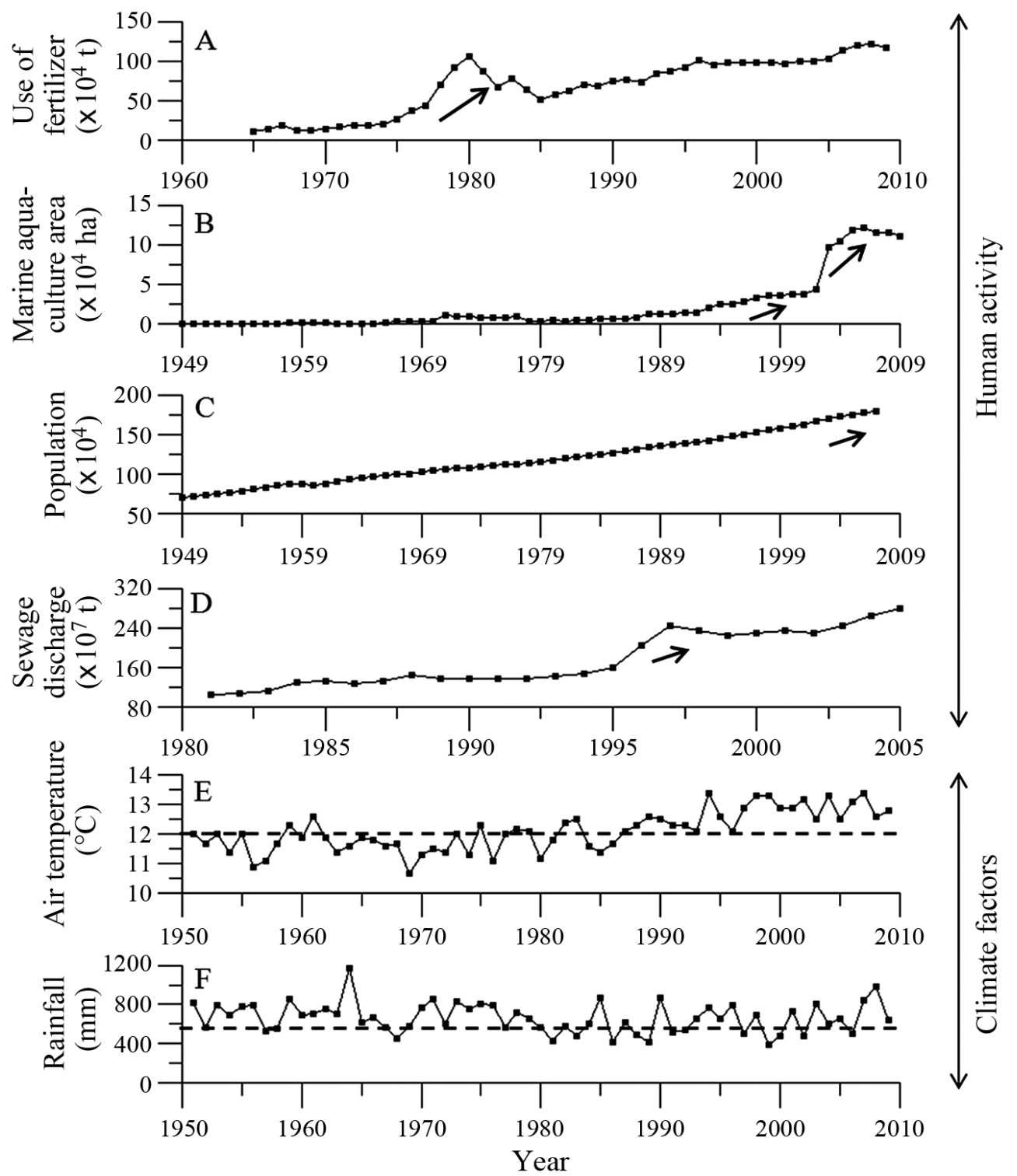

Fig. 8. Historical data of human activities and climatic factors around Yantai City: (A) fertilizer use; (B) marine aquaculture; (C) population; (D) sewage discharge; $(E)$ air temperature; $(F)$ rainfall. Slanted arrows indicate periods with an obvious increasing trend in the variable. Dashed line: midrange value to illustrate data variation

Table 2. Nutrient ranges and ratios in surface seawater between 1997-1998 and 2009-2010 in Sishili Bay at 12 sampling sites (1997-1998 survey from Zhao et al. 2000; 2009-2010 survey from Jiang et al. 2011). DIN: dissolved inorganic nitrogen, DIP: dissolved inorganic phosphorus, DSi: dissolved silicate

\begin{tabular}{|c|c|c|c|c|c|c|c|}
\hline Survey date & & $\begin{array}{l}\text { DIN } \\
(\mu \mathrm{M})\end{array}$ & $\begin{array}{l}\text { DIP } \\
(\mu \mathrm{M})\end{array}$ & $\begin{array}{c}\mathrm{DSi} \\
(\mu \mathrm{M})\end{array}$ & $\mathrm{N}: \mathrm{P}$ & Si:N & $\mathrm{Si}: \mathrm{P}$ \\
\hline May & $\begin{array}{l}1997-1998 \\
2009-2010\end{array}$ & $\begin{array}{l}0.8-1.5 \\
0.8-17.3\end{array}$ & $\begin{array}{l}0.12-0.18 \\
0.02-0.33\end{array}$ & $\begin{array}{r}0-3.0 \\
0.9-1.7\end{array}$ & $\begin{array}{r}7.2 \\
36.7\end{array}$ & $\begin{array}{l}0.87 \\
0.27\end{array}$ & $\begin{array}{r}6.3 \\
10.3\end{array}$ \\
\hline August & $\begin{array}{l}1997-1998 \\
2009-2010\end{array}$ & $\begin{array}{l}0.7-5.1 \\
2.5-11.8\end{array}$ & $\begin{array}{r}0.11-0.26 \\
0-0.49\end{array}$ & $\begin{array}{r}0-1.1 \\
1.2-5.3\end{array}$ & $\begin{array}{r}8.9 \\
83.6\end{array}$ & $\begin{array}{l}0.33 \\
0.40\end{array}$ & $\begin{array}{r}2.9 \\
33.2\end{array}$ \\
\hline November & $\begin{array}{l}1997-1998 \\
2009-2010\end{array}$ & $\begin{array}{l}3.1-13.2 \\
5.0-25.0\end{array}$ & $\begin{array}{l}0.60-1.06 \\
0.11-0.58\end{array}$ & $\begin{array}{l}8.8-21.4 \\
2.0-7.6\end{array}$ & $\begin{array}{r}8.5 \\
44.8\end{array}$ & $\begin{array}{l}1.93 \\
0.30\end{array}$ & $\begin{array}{l}16.4 \\
13.6\end{array}$ \\
\hline March & $\begin{array}{l}1997-1998 \\
2009-2010\end{array}$ & $\begin{array}{l}7.0-32.1 \\
4.8-50.1\end{array}$ & $\begin{array}{l}0.47-1.06 \\
0.01-1.17\end{array}$ & $\begin{array}{r}3.5-12.0 \\
10.2-16.8\end{array}$ & $\begin{array}{r}17.5 \\
116.3\end{array}$ & $\begin{array}{l}0.69 \\
0.68\end{array}$ & $\begin{array}{l}11.9 \\
79.1\end{array}$ \\
\hline
\end{tabular}


Aug

2009
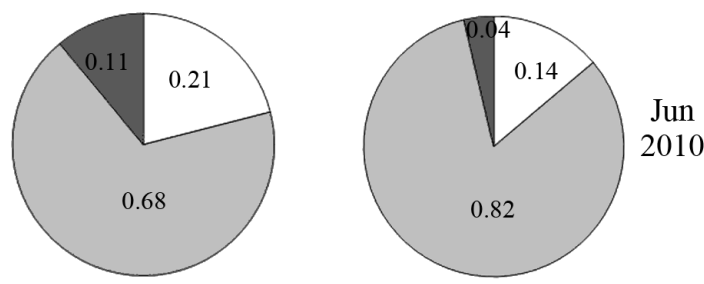

Oct

2009

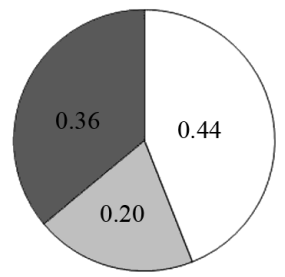

Dec

2009
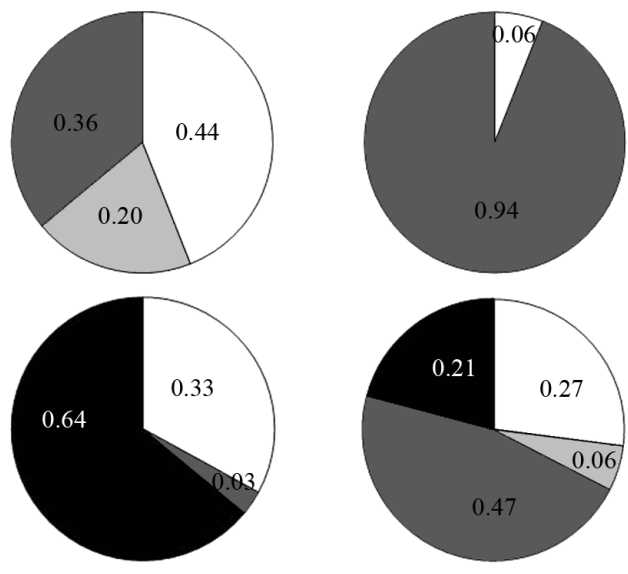

Aug

2010

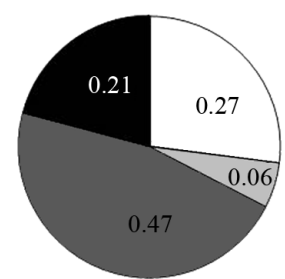

Oct

2010
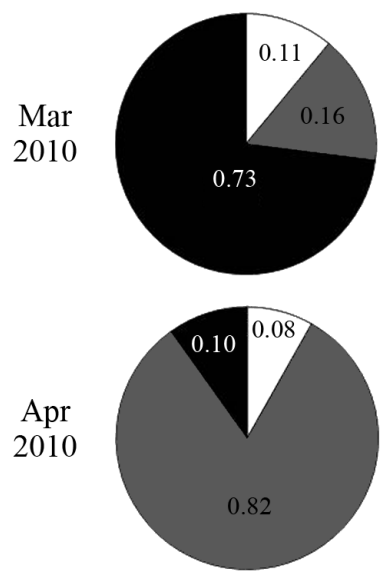

Paralia
sulcata

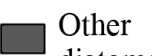

diatoms
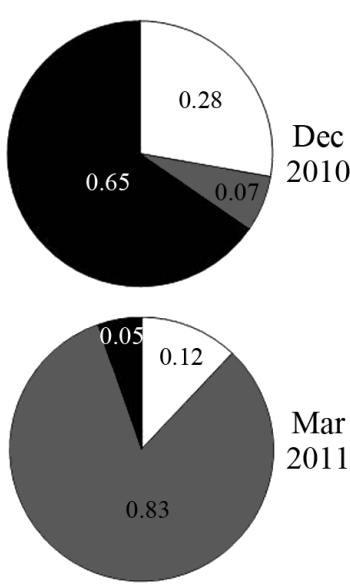

Mar 2011

Fig. 9. Seasonal patterns of phytoplankton assemblages in Sishili Bay during 2009 to 2011

gen (DIN) concentrations increased much faster than those of dissolved inorganic phosphorus (DIP) and dissolved silicate (DSi), leading to seasonal $\mathrm{P}$ and $\mathrm{Si}$ limitations (Table 2). In autumn and spring, the probability of P limitation in Sishili Bay reached to $70 \%$; the probability of Si limitation in Sishili Bay increased to $94 \%$ from spring to summer (Y. Wang et al. 2012).

P- or Si-limitation shift phytoplankton assemblages from diatom dominance to non-siliceous opportunistic species (e.g. coccolithophores, dinoflagellates) (e.g. North Sea and Chesapeake Bay; Dortch et al. 2001, Marshall et al. 2009), as diatoms are poor competitors at low phosphate concentrations (Egge
1998). In our study, the small diatoms Cyclotella stylorum $(30-66 \mu \mathrm{m})$ and Paralia sulcata $(15-36 \mu \mathrm{m})$ with heavily silicified frustules became dominant over the large diatom Coscinodiscus radiatus (89$115 \mu \mathrm{m})$, and dinoflagellate biomass also increased since 1975. Shifts in phytoplankton communities from diatom species in favour of nanoplankton and flagellates lead to increased non-diatom blooms (Anderson et al. 2002), as observed in Sishili Bay (Table 1, Fig. 9).

When diatom abundance increases quickly during eutrophication, silicate limitation may affect diatom valve synthesis, resulting in specimens of reduced size or with light frustules (Conley et al. 1993). However, small and heavily silicified diatoms may become abundant during eutrophication (e.g. Huang et al. 1996, McQuoid \& Nordberg 2003, Liu et al. 2008, Olli et al. 2008). For example, Paralia sulcata has become the most abundant species in many eutrophic water bodies, especially in waters with high concentrations of dissolved nitrogen (McQuoid \& Nordberg 2003). Di et al. (2013) studied diatom frustules in the surface sediment of Sishili Bay and found that $P$. sulcata dominated at most stations.

Beucher et al. (2004) found that biosilica production and dissolution rates vary among species. Thick frustules could slow down the rate of biosilica dissolution and increase the residence time of biosilica in the sediment; this can decrease the amount of DSi in sediment-water fluxes and drive the water system to extreme DSi limitation. For example, Olli et al. (2008) found a long delay in Si recycling in the Gulf of Riga after the spring bloom of the thick frustule diatom Thalassiosira baltica exhausted DSi availability; and assumed this to be an important reason for dinoflagellate dominance in summer. Jiang et al. (2011) showed that diatoms were dominant in Sishili Bay during most of the year except in summer (e.g. August 2009 and June 2010; Fig. 9). In particular, the small and heavily silicified diatom Paralia sulcata dominated greatly in winter and spring (Fig. 9), and this corresponds to its dominance in the sediment core. In a result similar to results reported from the Gulf of Riga (Olli et al. 2008), dinoflagellates became dominant and frequently caused blooms in summer after the spring bloom of P. sulcata in Sishili Bay. Thus, the diatom and dinoflagellate shifts may coincide in the sedimentary record. The regime shift was triggered by altered nutrient supply ratios after eutrophication, and may also have been favored by slow biosilica recycling due to the shift in the dominant diatom species, which can promote favourable conditions for dinoflagellates to out-compete diatoms in summer. 
Acknowledgements. We thank Y. Chen at YIC-CAS and Q. Sun at China East Normal University for assistance during sample analysis. The study was funded by the Chinese Academy of Sciences Innovative Programme (No. KZCX2YW-Q07-04) and the Natural Science Foundation of China (No. 40976097).

\section{LITERATURE CITED}

Andersen JH, Conley DJ, Hedal S (2004) Palaeoecology, reference conditions and classification of ecological status: the EU Water Framework Directive in practice. Mar Pollut Bull 49:283-290

Anderson DM, Glibert PM, Burkholder JM (2002) Harmful algal blooms and eutrophication: nutrient sources, composition, and consequences. Estuaries 25(4b):704-726

> Appleby PG, Oldfield F (1978) The calculation of ${ }^{210} \mathrm{~Pb}$ dates assuming a constant rate of supply of unsupported ${ }^{210} \mathrm{~Pb}$ to the sediment. Catena 5:1-8

Appleby PG, Nolan PJ, Grifford DW, Godfrey MJ, Oldfield F, Anderson NJ, Battarbee RW (1986) ${ }^{210} \mathrm{~Pb}$ dating by low background gamma counting. Hydrobiologia 141:21-27

Barrett SM, Volkman JK, Dunstan GA, LeRoi JM (1995) Sterols of 14 species of marine diatoms (Bacillariophyta). J Phycol 31:360-369

Battarbee RW, Jones VJ, Flower RJ, Cameron NG, Bennion H, Carvalho L, Juggins S (2001) Diatoms. In: Smol JP, Birks HJB, Last WM (eds) Tracking environmental change using lake sediments, Vol 3. Terrestrial, algal and siliceous indicators. Kluwer, Dordrecht, p 155-202

- Beucher C, Tréguer P, Corvaisier R, Hapette AM, Elskens M (2004) Production and dissolution of biosilica, and changing microphytoplankton dominance in the Bay of Brest (France). Mar Ecol Prog Ser 267:57-69

> Billen G, Garnier J (1997) The Phison River plume: coastal eutrophication in response to changes in land use and water management in the watershed. Aquat Microb Ecol 13:3-17

> Canfield DE (1994) Factors influencing organic carbon preservation in marine sediments. Chem Geol 114: 315-329

> Chai C, Yu Z, Song X, Cao X (2006) The status and characteristics of eutrophication in the Yangtze river (Changjiang) estuary and the adjacent East China Sea, China. Hydrobiologia 563:313-328

> Clarke AL, Weckström K, Conley DJ, Anderson NJ and others (2006) Long-term trends in eutrophication and nutrients in the coastal zone. 2. Eutrophication of freshwater and marine ecosystems. Limnol Oceanogr 51:385-397

> Conley DJ, Schelske CL, Stoermer EF (1993) Modification of the biogeochemical cycle of silica with eutrophication. Mar Ecol Prog Ser 101:179-192

> Cooper SR (1995a) Chesapeake Bay watershed historical land use: impact on water quality and diatom communities. Ecol Appl 5:703-723

$>$ Cooper SR (1995b) Diatoms in sediment cores from the mesohaline Chesapeake Bay, U.S.A. Diatom Res 10:39-89

> Cornwell JC, Conley DJ, Owens YM, Stephenson JC (1996) A sediment chronology of the eutrophication of Chesapeake Bay. Estuaries 19:488-499

Dale B (2009) Eutrophication signals in the sedimentary record of dinoflagellate cysts in coastal waters. J Sea Res 61:103-113

de Jonge VN, Essink K (1991) Long-term changes in nutrient loads and primary and secondary production in the Dutch Wadden Sea. In: Elliott M, Ducrotoy JP (eds)
Estuaries and coasts: spatial and temporal intercomparisons. International Symposium Series. Olsen \& Olsen, Fredensborg, p 307-316

> de Jonge VN, Elliott M, Orive E (2002) Causes, historical developments, effects and future challenges of a common environmental problem: eutrophication. Hydrobiologia 475-476:1-19

> Di B, Liu D, Wang Y, Dong Z, Li X, Shi Y (2013) Diatom and silicoflagellate assemblages in modern surface sediments associated with human activity: a case study in Sishili Bay, China. Ecol Indic 24:23-30

Dortch Q, Rabalais NN, Turner RE, Qureshi NA (2001) Impacts of changing $\mathrm{Si} / \mathrm{N}$ ratios and phytoplankton species composition. In: Rabalais NN, Turner RE (eds) Coastal hypoxia: consequence for living resources and ecosystems. Coast Estuar Stud Ser 58:37-48

Egge JK (1998) Are diatoms poor competitors at low phosphate concentrations? J Mar Syst 16:191-198

Egge JK, Aksnes DL (1992) Silicate as regulating nutrient in phytoplankton competition. Mar Ecol Prog Ser 83: 281-289

Ellegaard M, Clarke AL, Reuss N, Drew S and others (2006) Multi-proxy evidence of long-term changes in ecosystem structure in a Danish marine estuary, linked to increased nutrient loading. Estuar Coast Shelf Sci 68:567-578

Feifel KM, Moore SK, Horner RA (2012) An Alexandrium spp. cyst record from Sequim Bay, Washington State, USA, and its relation to past climate variability. J Phycol 48:550-558

Ge M, Feng Z (2009) Population distribution of China based on GIS: classification of population densities and curve of population gravity centers. Acta Geophys Sin 64: 202-210 (in Chinese)

> Harley CDG, Hughes AR, Hultgren KM, Miner BG and others (2006) The impacts of climate change in coastal marine systems. Ecol Lett 9:228-241

Hickel W, Mangelsdorf P, Berg J (1993) The human impact in the German Bight: eutrophication during three decades (1962-1991). Helgol Meersunters 47:243-263

- Hinrichs KU, Schneider RR, Müller PJ, Rullkötter J (1999) A biomarker perspective on paleoproductivity variations in two Late Quaternary sediment sections from the southeast Atlantic Ocean. Org Geochem 30:341-366

Huang B, Hong H, Wong Y (1996) Diatoms in the sediments of Victoria Harbour, Hong Kong. In: Morton B (ed) Asia marine biology 13. Hong Kong University Press, Hong Kong, p 45-51

Huang XP, Huang LM, Yue WZ (2003) The characteristics of nutrients and eutrophication in the Pearl River estuary, South China. Mar Pollut Bull 47:30-36

Jiang J, Liu D, Di B, Dong Z, Wang Y, Shi Y (2011) Seasonal changes of phytoplanktion community and its indication of environment in Sishili Bay, Yantai. Acta Oceanol Sin 33:151-164 (in Chinese)

Leblond JD, Chapman PJ (2000) Lipid class distribution of highly unsaturated long-chain fatty acids in marine dinoflagellates. J Phycol 36:1103-1108

- Leblond JD, Lasiter AD, Li C, Logares R, Rengefors K, Evens TJ (2010) A data mining approach to dinoflagellate clustering according to sterol composition: correlations with evolutionary history. Int J Data Min Bioinform 4:431-451

Lignum J, Jarvis I, Pearce M (2008) A critical assessment of standard processing methods for the preparation of palynological samples. Rev Palaeobot Palynol 149:133-149

$>$ Liu D, Sun J, Zhang J, Liu G (2008) Response of the diatom flora in Jiaozhou Bay, China to environmental changes during the last century. Mar Micropaleontol 66:279-290 
Marret F, Scourse J (2003) Control of modern dinoflagellate cyst distribution in the Irish and Celtic Seas by seasonal stratification dynamics. Mar Micropaleontol 47:101-116

Marshall HG, Lane MF, Nesius KK, Burchardt L (2009) Assessment and significance of phytoplankton species composition within Chesapeake Bay and Virginia tributaries through a long-term monitoring program. Environ Monit Assess 150:143-155

Matsuoka K, Fukuyo Y (2000) Technical guide for modern dinoflagellate cyst study. Westpac-Hab/Westpac/Ioc. University of Tokyo, Tokyo

Meyers PA (1994) Preservation of elemental and isotopic source identification of sedimentary organic matter. Chem Geol 144:289-302

McQuoid MR, Nordberg K (2003) The diatom Paralia sulcata as an environmental indicator species in coastal sediments. Estuar Coast Shelf Sci 56:339-354

- Morán XAG, López-Urrutia Á, Calvo-Díaz A, Li WKW (2010) Increasing importance of small phytoplankton in a warmer ocean. Glob Change Biol 16:1137-1144

- Mouradian M, Panetta RJ (2007) Dinosterols or dinocysts to estimate dinoflagellate contributions to marine sedimentary organic matter. Limnol Oceanogr 52:2569-2581

Olli K, Clarke A, Danielsson A, Aigars J, Conley DJ, Tamminen $T$ (2008) Diatom stratigraphy and long-term dissolved silica concentrations in the Baltic Sea. J Mar Syst 73:284-299

Parsons ML, Dortch Q, Turner RE, Rabalais NN (1999) Salinity history of coastal marshes reconstructed from diatom remains. Estuaries 22:1078-1089

Parsons ML, Dortch Q, Turner RE (2002) Sedimentological evidence of an increase in Pseudo-nitzschia (Bacillariophyceae) abundance in response to coastal eutrophication. Limnol Oceanogr 47:551-558

Parsons ML, Dortch Q, Turner RE, Rabalais NR (2006) Reconstructing the development of eutrophication in Louisiana salt marshes. Limnol Oceanogr 51:534-544

Partal T, Kahya E (2006) Trend analysis in Turkish precipitation data. Hydrol Process 20:2011-2026

Rousseau L, Keraudren B, Pèpe C, Laurent M, Blanc J (1995) Sterols as biogeochemical markers in Pliocene sediments and their potential application for the identification of marine facies. Quat Sci Rev 14:605-608

Sabetta L, Fiocca A, Margheriti L, Vignes F and others (2005) Body size-abundance distributions of nano- and micro-phytoplankton guilds in coastal marine ecosystems. Estuar Coast Shelf Sci 63:645-663

Schubert CJ, Villanueva J, Calvert SE, Cowie GL and others (1998) Stable phytoplankton community structure in the Arabian Sea over the past 200,000 years. Nature 394: 563-566

Schulte S, Bard E (2003) Past changes in biologically mediated dissolution of calcite above the chemical lysocline recorded in Indian Ocean sediments. Quat Sci Rev 22: $1757-1770$

Smetacek V, Cloern JE (2008) On phytoplankton trends. Science 319:1346-1348

SPOFD (Shandong Provincial Oceanic and Fishery Department, PR China) (2005) Report on the marine environmental quality in Shandong, P. R. China, SOA, Jinan (in Chinese)

SPOFD (2008) Report on the marine environmental quality in Shandong, P. R. China, SOA, Jinan (in Chinese)

Stein R (1991) Accumulation of organic carbon in marine sediments. Springer-Verlag, Berlin
Sun MY, Wakeham SG (1998) A study of oxic/anoxic effects on degradation of sterols at the simulated sediment-water interface of coastal sediments. Org Geochem 28:773-784

> Volkman JK (2003) Sterols in microorganisms. Appl Microbiol Biotechnol 60:495-506

> Volkman JK, Barrett SM, Blackburn SI, Mansour MP, Sikes EL, Gelin F (1998) Microalgal biomarkers: a review of recent research developments. Org Geochem 29:1163-1179

Wang B, Wang X, Zhan R (2003) Nutrient conditions in the Yellow Sea and the East China Sea. Estuar Coast Shelf Sci 58:127-136

Wang WX, Li MJ (1997) Design scheme of technology and marine structures of sewage disposal and drainage into sea in Yantai. Coast Eng 16:30-35 (in Chinese)

Wang X, Cui Z, Guo Q, Han X, Wang J (2009) Distribution of nutrients and eutrophication assessment in the Baohai Sea of China. Chin J Oceanol Limnol 27:177-183 (in Chinese)

Wang Y, Liu D, Dong Z, Di B, Shen X (2012) Temporal and spatial distributions of nutrients under the influence of human activities in Sishili Bay, northern Yellow Sea of China. Mar Pollut Bull 64:2708-2719

Wasmund N (2002) Harmful algal blooms in coastal waters of the south-eastern Baltic Sea. In: Schemewski G, Schiewer U (eds) Baltic coastal ecosystems. Springer, Berlin, p 93-116

> Werne JP, Hollander DJ, Lyons TW, Peterson LC (2000) Climate-induced variations in productivity and planktonic ecosystem structure from the Younger Dryas to Holocene in the Cariaco Basin, Venezuela. Paleoceanography 15: $19-29$

Withers N (1987) Dinoflagellate sterols. In: Taylor FJR (ed) The biology of dinoflagellates. Biological Monographs, Vol 21. Blackwell Scientific, Oxford, p 316-359

Wood GD, Gabriel AM, Lawson JC (1996) Palynological techniques - processing and microscopy. In: Jansonius J, McGregor DC (eds) Palynology: principles and applications, Vol 1. American Association of Stratigraphic Palynologists Foundation, Dallas, TX, p 29-50

Wu Y, Zhou C, Zhang Y, Pu X, Li W (2001) Evolution and causes of formation of Gymnodinium sanguineum bloom in Yantai Sishili Bay. Chin J Oceanol Limnol 32:159-167 (in Chinese)

Yantai Statistics Bureau (2009) Yantai statistical yearbook. China Statistics Press, Beijing (in Chinese)

Ye M, Sun H, Gao Y, Lin Y and others (2006) Production and feature of nutrition at Sishili Harbor in Yantai. Environ Monit China 22:88-91 (in Chinese)

Yu L, Hao Y (2009) Process analysis for harmful bloom of Akashiwo sanguinea in Sishili Bay of Yantai. Adv Mar Sci 27:516-522 (in Chinese)

Zhang R, Dong Y (1990) Analysis of conditions of natural environment in sea areas for pollutant discharge and the study on pathways of pollutant transport in Yantai. Coast Eng 9:35-44 (in Chinese)

Zhao W, Jiao N, Zhao Z (2000) Distribution and variation of nutrients in the Yantai Sishili Bay cultivated water. Mark Sci 24:31-34 (in Chinese)

Zhou MJ, Zhu MY, Zhang J (2001) Status of harmful algal blooms and related research activities in China. Life Sci 13:54-59 (in Chinese)

Zhou Y, Yang HS, Zhang T, Liu SL and others (2006) Influence of filtering and biodeposition by the cultured scallop Chlamys farreri on benthic-pelagic coupling in a eutrophic bay in China. Mar Ecol Prog Ser 317:127-141

Submitted: June 22, 2012; Accepted: December 19, 2012

Proofs received from author(s): February 5, 2013 